\title{
Characteristics of genetic fund of Caucasian breed of sheep
}

\author{
S.A. KAZANOVSKY, T.A. ANFINOGENOVA, V.I. OSTAPENKO, \\ L.V. OLKHOVSKAYA and MARZANOV \\ All-Union Sheep and Goat Research Institute, Stavropol, U.S.S.R.
}

It has been established that antigens $\mathrm{Aa}, \mathrm{Ab}, \mathrm{Bg}, \mathrm{Bd}, \mathrm{Bh}, \mathrm{Be}, \mathrm{F}_{3}, \mathrm{Cb}, \mathrm{F}_{6}, \mathrm{~F}_{32}, \mathrm{Mb}, \mathrm{R}, \mathrm{O}$, Da, $F_{30}, F_{41}$, PLB-17, PLB-25/1 and PLB-25/2 prevail in Caucasian sheep (frequency 36.79I p. 100) and antigens $F_{5}$ and $F_{16}$ are completely absent. Of highest genetic frequency were If ${ }^{A}$ (0.433), Tf $\mathrm{Tf}^{\mathrm{C}}(0.437), \mathrm{Hb}^{\mathrm{B}}(0.883), \mathrm{Ca}^{\mathrm{S}}(0.984), \mathrm{AEs}^{\mathrm{B}}(0.543), \mathrm{Ap}^{\mathrm{B}}(0.549), \mathrm{Al}^{\mathrm{D}}(0.527)$, and lowest were $\mathrm{Tf}^{\mathrm{D}}(0.031), \mathrm{Tf}^{\mathrm{E}}(0.004), \mathrm{Ap}^{\mathrm{A}}(0.004), \mathrm{Al}^{\mathrm{S}}(0.045)$. Animals with $\mathrm{Tf} \mathrm{AC}(39.0 \mathrm{p} .100)$, Hb BB (78.1 p. 100), Ca SS (97.6 p. 100), Ap BC (43.3 p. 100), Al DD (33.0 p. 100), Al DF (34.8 p. 100), prevailed. Sheep with Tf EE were not found.

\section{Genetic distance for serum protein complex of some particular local cattle breeds of Eastern Europe}

\author{
A.A. ISTOMIN, Z.P. LJUBIMOVA and A.S. STRELKOVSKY
}

All-Union Research Institute of Farm Animal Breeding and Genetics, Leningrad, U.S.S.R.

Genetic distance index was used as a measure of polymorphism difference which excluded possible relationship of transferrin, ceruloplasmin and amilase I loci. On the basis of distance values the polymorphism clines of Suksunsky cattle have been established which resemble those of Red cattle of Western Europe. The isolation of the Istobenskaya breed as compared to local cattle populations of the areas adjacent to the Urals has been revealed. An indirect influence of the Asian component on the determination of polymorphism was found to be less than of the European component.

\section{Gene pool of Black-and-white cattle breeds for polymorphous systems and milk performance}

\section{T.A. PAVLYUCHENKO and G.V. PUPKOVA}

All-Union Research Institute of Farm Animal Breeding and Genetics, Leningrad, U.S.S.R.

The gene pool of five breeds of black-and-white cattle was studied by polymorphous protein systems and their relationship with milk performance was established. Specific aspects of breed genetic structure and associations between complex genotype combinations of polymorphous proteins and milk performance data were revealed. 